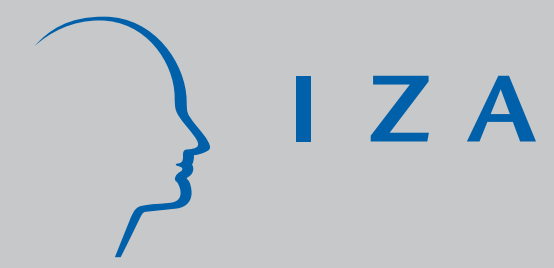

IZA DP No. 1020

Profit Sharing, Credit Market Imperfections and Equilibrium Unemployment

Erkki Koskela

Rune Stenbacka

February 2004 


\title{
Profit Sharing, Credit Market Imperfections and Equilibrium Unemployment
}

\author{
Erkki Koskela \\ University of Helsinki and IZA Bonn \\ Rune Stenbacka \\ Swedish School of Economics \\ Discussion Paper No. 1020 \\ February 2004
}

IZA
P.O. Box 7240
53072 Bonn
Germany

Phone: +49-228-3894-0

Fax: +49-228-3894-180

Email: iza@iza.org

\begin{abstract}
Any opinions expressed here are those of the author(s) and not those of the institute. Research disseminated by IZA may include views on policy, but the institute itself takes no institutional policy positions.
\end{abstract}

The Institute for the Study of Labor (IZA) in Bonn is a local and virtual international research center and a place of communication between science, politics and business. IZA is an independent nonprofit company supported by Deutsche Post World Net. The center is associated with the University of Bonn and offers a stimulating research environment through its research networks, research support, and visitors and doctoral programs. IZA engages in (i) original and internationally competitive research in all fields of labor economics, (ii) development of policy concepts, and (iii) dissemination of research results and concepts to the interested public.

IZA Discussion Papers often represent preliminary work and are circulated to encourage discussion. Citation of such a paper should account for its provisional character. A revised version may be available on the IZA website (www.iza.org) or directly from the author. 


\section{ABSTRACT \\ Profit Sharing, Credit Market Imperfections and Equilibrium Unemployment ${ }^{*}$}

We investigate the interaction between labour and credit market imperfections for equilibrium unemployment in the presence of profit sharing. In a partial equilibrium with exogenous outside options increased bargaining power of banks has adverse employment effects. In a general equilibrium with endogenous outside options this relationship is frequently reversed; reduced credit market imperfections increase equilibrium unemployment if the labour market imperfections - measured by the bargaining power of trade unions - are sufficiently strong and benefit-replacement ratio high enough. Finally, we show that higher bankruptcy risks increase equilibrium unemployment under similar conditions.

JEL Classification: J51, J41, G32

Keywords: wage and loan bargaining, compensation systems, equilibrium unemployment, outside options

Corresponding author:

Erkki Koskela

Department of Economics

University of Helsinki

P.O. Box 17 (Arkadiankatu 7)

00014 Helsinki

Finland

Email: erkki.koskela@helsinki.fi

\footnotetext{
* We thank Torben Andersen, Thomas Gehrig, Birgit Grodal, Heinz Herrmann, Daniel Hinze, Giovanni Lombardo, Peter Möllgaard, Ray Rees, Klaus Schmidt, Ronnie Schöb, Christian Schultz, Leopold von Thadden, two anonymous referees as well as seminar audiences at Deutsche Bundesbank, University of Munich, University of Copenhagen, University of Freiburg, University of Heidelberg, University of Magdeburg and at the IZA workshop "Interactions Between Labor and Financial Markets", Bonn, for helpful comments and Toni Nordlund for research assistance. The usual disclaimer holds. Koskela thanks the Research Unit of Economic Structures and Growth (University of Helsinki) and the Yrjö Jahnsson Foundation for financial support and CESifo at the University of Munich and Deutsche Bundesbank for their hospitality, wheras Stenbacka thanks The Yrjö Jahnsson Foundation for financial support. A shorter version is forthcoming in Scandinavian Journal of Economics.
} 


\section{Introduction}

For a long time it has been a major challenge for economists to explain the high and persistent European unemployment. Explanations have typically focused on labour market imperfections. However, to an increasing extent economists (see, for example, Acemoglu (2001), Blanchard and Giavazzi (2003) and Wasmer and Weil (2002)) have argued for various reasons that labour market frictions and wage rigidities do not constitute sufficiently rich explanations of the poor employment performance in European countries. For example, in their empirical study Krueger and Pischke (1997) (p.22) conclude that "restrictions on entrepreneurs and product market regulations and institutions may distort labour demand, causing the labour demand curve to shift in and become more inelastic". Also, the empirical results reported by Blanchflower and Oswald (1998) indicate that credit market imperfections have adverse employment effects by constituting an obstacle against self-employment.

In the present study we apply the "right-to-manage" framework to examine the interaction of labour and credit market imperfections for the determination of equilibrium unemployment in the presence of profit sharing. We capture the labour market imperfections by adopting a union bargaining approach, which seems reasonable as more than three quarters of the workforce are still covered by collective bargaining in most European countries. The idea of perfect competition basically seems equally unrealistic in credit markets as in labour markets. ${ }^{1}$ In line with our way of capturing imperfections in the labour market, banks are assumed to be equipped with bargaining power in the loan market. ${ }^{2}$ In this way we can capture the imperfections in labour and credit markets within a uniform analytical framework, which makes it possible to disentangle the effects on wage formation and employment associated with the imperfections in these markets.

We focus on credit markets, where repayment rates are negotiated between financiers and firms, whereas the firms and organised labour bargain over the base wage in the imperfectly competitive labour market. These two types of negotiations take place sequentially and are assumed to be conditional on the firm having committed itself to the form of wage contract determining to what extent it makes use of performance-

\footnotetext{
${ }^{1}$ See, for example, Sharpe (1990) or Dell'Arrichia et. al. (1999) for models demonstrating how informational asymmetries will create barriers to entry and make it possible for incumbent lenders to exploit captive customers.

${ }^{2}$ Of course, the imperfections in the credit market could take alternative forms. For example, the literature in financial economics often emphasizes the imperfections generated by asymmetric information.
} 
related profit sharing in addition to the negotiated base wage. Our ultimate goal is to study the impact of alternative outside options - largely related to labour force mobility as captured by a general equilibrium framework as opposed to a partial equilibrium framework -on the relationship between credit market imperfections and equilibrium unemployment in the presence of profit sharing. We also study the relationship between bankruptcy risks and equilibrium unemployment - an unexplored issue in the literature so far.

An emerging literature has focused on the interaction between corporate finance, wage and employment policies. Bronars and Deere (1991), Perotti and Spier (1993), Dasgupta and Sengupta (1993) as well as Dalmazzo (1996) demonstrate how firms can use debt as a strategic instrument to reduce the costs that unionised workers can impose on shareholders through their collective bargaining power. But this finance approach does not explore the implications of the interaction between the labour and credit markets for employment.

The literature focusing on the employment consequences of the interaction between credit and labour markets, both characterised by market imperfections, is currently quite thin. Wasmer and Weil (2002) investigate this issue within a framework with job search, labour and credit matching frictions and negotiated mark-ups in the labour and credit markets. Their model generates a decomposition of unemployment into two parts, one depending on labour market imperfections and the other one related to credit market imperfections. These imperfections exhibit interaction in the form of a credit multiplier such that the credit market imperfections amplify the unemployment generated through the imperfections in the labour market. ${ }^{3}$ Acemoglu (2001) presents another mechanism for how credit market frictions may contribute to unemployment. Abstracting from labour market imperfections he shows how failures in the credit market to channel funds to socially valuable projects can have a substantial employment effect, in particular in the "medium" run.

Our present analysis makes it possible to characterise the relationship between equilibrium unemployment and the competitiveness of the credit market for environments where firms apply performance-related wage contracts relying on profit sharing.

\footnotetext{
3 Our model differs in two important respects from that of Wasmer and Weil (2002). Firstly, our results heavily depend on the general equilibrium analysis, which is important, because, in contrast to studies based on a partial equilibrium analysis, wage increases affect the outside option available to union members. Secondly, we operate with more general wage contracts. In fact, most of the analysis in Wasmer and Weil is restricted to exogenous base wages with no performance-related elements.
} 
We study the important issue of how this relationship depends on the nature of the outside options relevant for the labour market negotiations. In our framework profit sharing, the performance-related wage component, turns out to be a critically important mechanism for creating a relationship between credit and labour market imperfections. The commitment to profit sharing serves as a strategic device inducing a reduction in the negotiated base wage, thereby generating a link between the imperfections in the credit market (measured by the bargaining power of financiers) and equilibrium unemployment.

We confirm the intuitively appealing conjecture that reduced credit market imperfections will promote employment under two distinct types of circumstances. These are (1) a partial equilibrium with exogenous outside options or (2) a general equilibrium with endogenous outside options when labour markets exhibit sufficiently small bargaining power of trade unions and face policies with sufficiently low benefitreplacement ratios. However, in a general equilibrium with the labour force being mobile across industries increased credit market imperfections will stimulate employment if the labour market imperfections - measured by the relative bargaining power of the trade union - are sufficiently significant. This seemingly paradoxical result can intuitively be explained as follows: A decrease in the repayment rate directly improves employment conditions, but it also induces a wage increase with the opposite effect. Moreover, a higher wage rate increases the value of the trade union's outside option so as to outweigh the decreased direct cost of financing. Finally, a lower degree of market imperfections in the credit market will induce lower profit shares. Even though lower profit shares will have no direct employment effect, they will depress employment by increasing the negotiated base wage. Thus, with sufficiently strong distortions in the labour market, due to the bargaining power of the trade union, an increase in the distortions present in the credit market will actually represent an efficiency-enhancing device by reducing the potential of the trade union to exploit its bargaining power.

Our analysis proceeds as follows. In section II we present the basic structure of the model including the time sequence of decisions under circumstances where a representative firm operates in an environment characterised by uncertainty and bankruptcy risk. Employment is studied in section III, while in section IV we analyse how the repayment rate, the base wage and profit share are determined. Section $\mathrm{V}$ 
explores the implications of credit market imperfections for equilibrium unemployment within the framework of partial and general equilibrium models, which affect the nature of outside options relevant for wage negotiations. In this section we also study the relationship between bankruptcy risks and equilibrium unemployment. Finally, we summarise and offer concluding comments in section VI.

\section{The Basic Framework}

We consider a financially constrained firm operating in an environment characterised by uncertainty. Production requires the firm to employ homogeneous workers within the framework of a unionised labour market. By employing labour input $L$ the firm is able to generate random revenues, $\gamma$, which are distributed continuously with $\gamma>0$ according to the conditional density function ${ }^{4}$

$$
f(\gamma \mid L)=\lambda(L) e^{-\lambda(L) \gamma}
$$

where the hazard rate function $\lambda(L)$ has the following properties: $\quad \lambda^{\prime}(L)<0$ and $\lambda^{\prime \prime}(L)>0$. Thus, a rise in $L$ shifts the density function to higher returns at a decreasing rate.

In order to focus on the interaction between imperfections in credit and labour markets we assume that the firm has to finance its operations exclusively by debt. The total remuneration of workers comprises the negotiated base wage and the profit share. It is assumed that the base wages are paid prior to the finalisation of the production process. Thus, the base wages have to be financed by debt, whereas potential profit shares are paid out after the revenues are realized and the demands of senior claimants are fulfilled. For a firm facing a credit market with a prevailing interest rate $r$, the effective base wage can be written as $(1+r) w=\Delta w=\widetilde{w}$, where $\Delta$ is the repayment rate. Faced with an ordinary debt contract exhibiting limited liability, the risk-neutral firm decides on employment, $L$, in order to maximise its net expected profits

\footnotetext{
${ }^{4}$ A more general form of this specification has been used in Koskela - Stenbacka (2000a).
} 


$$
(1-\tau) E \pi(L)=(1-\tau) \int_{\hat{\gamma}}^{\infty}(\gamma-\widetilde{w} L) f(\gamma \mid L) d \gamma=(1-\tau) \frac{e^{-\lambda(L) \hat{\gamma}}}{\lambda(L)} .
$$

where $\tau$ is the profit share paid to organised labour and where we have applied integration by parts and used the specification (1). In (2) the lower bound of the range of integration, $\hat{\gamma}=\widetilde{w} L$, denotes the "break-even" state of nature, in which the firm is just able to remain solvent. The generated conditional revenues are either sufficient to make the firm survive or not. According to (2) the firm's attention is restricted to the upper tail of the distribution of project returns $(\gamma \geq \hat{\gamma})$. The firm is bankrupt when $\gamma<\hat{\gamma}$ and in this case ownership of the project shifts to the bank. The remaining returns depend on the liquidation cost of a bankrupt project in a way we present later on.

In the long run the firm is assumed to commit itself to the form of the wage contract delineating to what extent it will make use of performance-related profit sharing. The profit share, $\tau$, determines what fraction of the firm's profits will be transferred to employed workers. Conditional on the structure of compensation to organised labour the firm and the trade union engage in base wage bargaining. Conditional on the outcome of the wage bargaining, in its turn, the firm and the bank negotiate over the firm's repayment rate $\Delta=1+r$.

It should be emphasized that profit sharing is, in fact, an empirically important phenomenon in many OECD countries. The OECD Employment Outlook (1995) reports cross-country evidence on the incidence of profit sharing in OECD countries. Pendleton et. al. (2001) presents more recent and detailed data on the significant proportion of workplaces with financial employee participation, in particular in the form of profit sharing schemes, in EU-countries. This information is illustrated in Figure 1. For example, among EU-countries in 1999/2000 a double-digit percentage of the workplaces apply profit sharing in Austria, Finland, France, Germany Ireland, Netherlands, Portugal, Spain, Sweden and United Kingdom. In some countries with particularly extensive profit sharing systems, like France, public policy explicitly encourages profit sharing. For further detailed evidence regarding the incidence of profit sharing we refer to, for example, DICE database collected by CESifo, http://www.CESifo.de, Wadhwani and Wall (1990), Cahuc and Dormont (1997) as well as Conyon and Freeman (2001). These sources also report on the country-specific institutional regulations surrounding the profit sharing systems. 


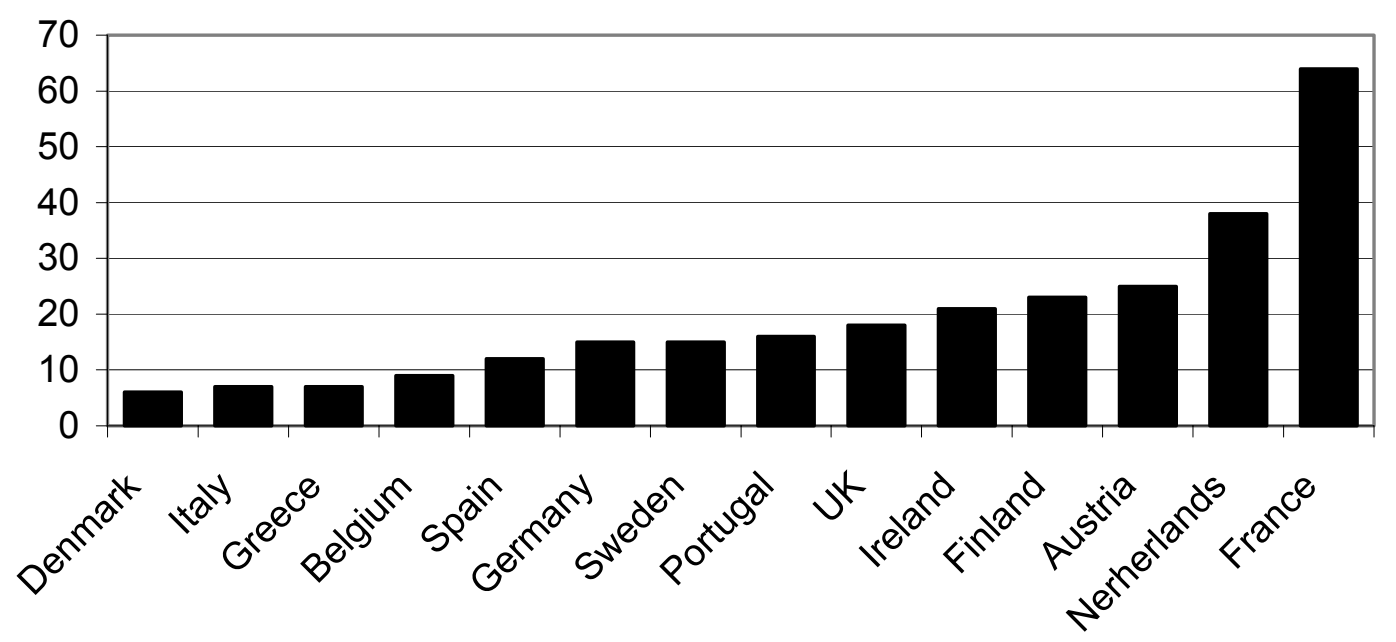

Figure 1. Workplaces with Profit Sharing in Percent, 1999/2000

Together with the negotiated base wage the repayment rate determines the effective cost of production for the firm. We apply the Nash bargaining solution as the outcome of the firm-financier negotiations determining the firm's cost of debt financing. Finally, the firm unilaterally decides on employment once the negotiations in the labour and credit markets are settled. This sequential bargaining is essential for our purpose of studying how the interaction between labour and credit markets impacts on equilibrium unemployment. $^{5}$

We summarise the time sequence of the decisions made by the firm, the financier and the trade union in Figure 2. The firm is assumed to commit itself to a profit sharing arrangement prior to the stage of base wage bargaining. This timing structure is designed so as to capture the typical, legally imposed, institutional feature whereby the profit sharing schemes have to be independent of the wage agreements ${ }^{6}$ (see, for example, Cahuc and Dormont (1997) or Pendleton et. al. (2001)). ${ }^{7}$ However, at the end of sections IV and V we briefly compare the outcomes of this sequential determination of profit shares and base wages with those associated with simultaneous bargaining with respect to profit shares and base wages.

\footnotetext{
${ }^{5}$ Koskela and Stenbacka (2001) have explored the implications of alternative timing sequences within the context of a related model.

${ }^{6}$ For example, in France, where the reported proportion of workplaces with profit sharing exceeds $50 \%$, firms can qualify for tax exemptions if they apply profit sharing schemes, which stipulate bonuses which are independent of the negotiated base wage.

${ }^{7}$ In their paper with a different focus Caballero and Hammour (1998) have abstracted from the interaction between labour and credit markets by assuming block bargaining (workers versus financiers and firms).
} 
Stage $1 \quad$ Stage $2 \quad$ Stage $3 \quad$ Stage $4 \quad$ Stage 5

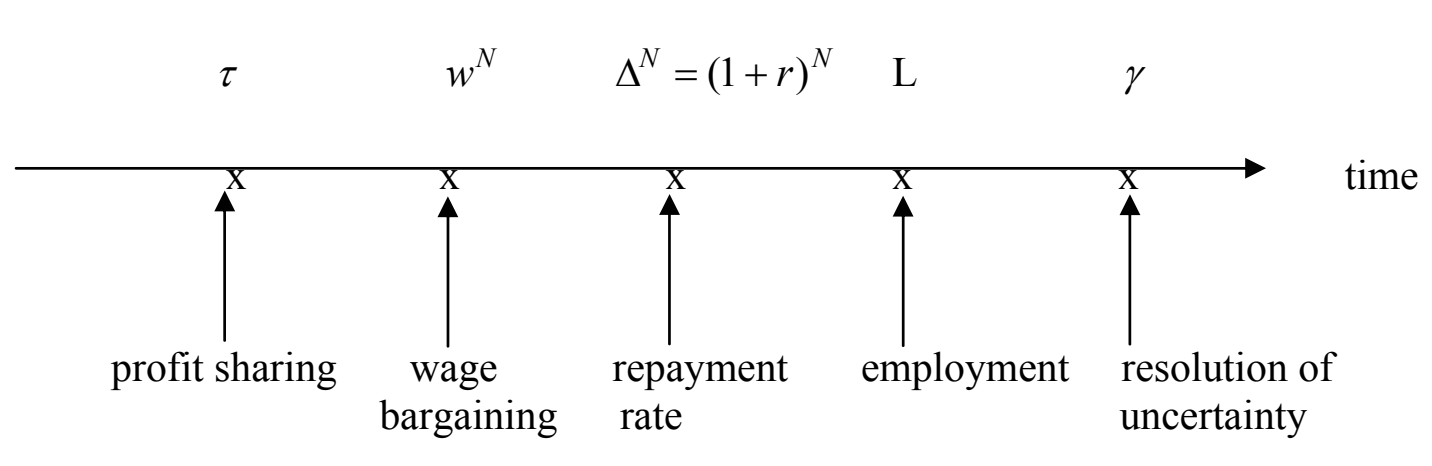

Figure 2: $\quad$ Time sequence of decisions

By applying backward induction we proceed by first investigating the determination of employment in the next section.

\section{Employment Determination}

At this stage the firm has committed itself to a profit sharing system and the negotiations in the labour and credit markets have fixed the base wage and the repayment rate. Thus, the effective cost of employing $\mathrm{L}$ workers can be expressed as $w \Delta L$, thereby exhibiting its dependence on the negotiated base wage and repayment rate, respectively. In order to simplify the presentation we make the following assumption ${ }^{8}$ regarding the production technology.

Assumption 1: The hazard rate function $\lambda(L)$ is assumed to satisfy

$$
\lambda(L)=\frac{\alpha}{L^{\alpha}} \quad \text { with } 0<\alpha<1
$$

Assumption (A1) implies that $\lambda^{\prime}(L)=-\alpha^{2} / L^{\alpha+1}<0$ and $\lambda^{\prime \prime}(L)=\alpha^{2}(\alpha+1) / L^{\alpha+2}>0$ so that an increase in employment shifts the density to higher returns at a decreasing rate. We differentiate (2) with respect to $L$ to obtain the first-order condition

$$
-\lambda^{\prime}(L)[1+\lambda(L) \hat{\gamma}]-\lambda(L)^{2} \widetilde{w}=0
$$

\footnotetext{
${ }^{8}$ In what follows the derivatives are noted by primes for functions with one argument and the partial derivatives by subscripts for functions with many arguments. Hence for example $\lambda^{\prime}(L)=d \lambda(L) / d L$, while $A_{x}(x, y)=\partial A(x, y) / \partial x$, etc.
} 
Using (A1) we can express the firm's optimal employment $L^{*}$ according to

$$
L^{*}=\widetilde{w}^{-\eta} \eta^{\eta}
$$

where $\eta \equiv 1 /(1-\alpha)$ is the elasticity of employment with respect to the effective wage rate $\widetilde{w}=\Delta w$. According to (4) the employment exhibits constant elasticity with respect to the wage and the repayment rates. As an increased interest rate contributes to the firm's leverage, (4) suggests that the higher is the firm's leverage rate, the lower is employment, ceteris paribus. Notice that labour demand does not depend directly on the profit sharing parameter $\tau$. ${ }^{9}$ Substituting (4) into the firm's expected profit function yields the expected indirect profit function

$$
(1-\tau) E \pi^{*}(\Delta)=(1-\tau) \frac{e^{-\lambda\left(L^{*}\right) \hat{\gamma}}}{\lambda\left(L^{*}\right)} .
$$

As the negotiating parties in the credit and labour markets anticipate the firm's employment decision, (5) is the relevant profit expression for the subsequent bargaining analyses.

\section{Nash Bargaining in the Credit and Labour Markets}

We now turn to the determination of the cost of external funds, which comprises the repayment rate, $\Delta$, determined in the credit market, as well as the labour costs, determined through the base wage, $w$, and the profit share, $\tau$.

\section{1. Repayment Rate Bargaining}

The financier of the firm's project, the bank, is assumed to be risk-neutral and we express its expected profit function as

\footnotetext{
${ }^{9}$ Empirical evidence from USA (see e.g. Sharpe (1994) and Hanka (1998)), from UK (see e.g. Nickell and Wadhwani (1991) and Nickell and Nicolitsas (1999)) as well as from Germany (see e.g. Funke, Maurer and Strulik (1999)) lies in conformity with the prediction that the firm's leverage will have a negative effect on employment. Moreover, direct employment independence of the profit share also lies in conformity with empirical evidence from UK (see Wadhwani and Wall (1990)) and France (see Cahuc and Dormont (1997)), but, of course, this does not mean an overall absence of employment effects.
} 


$$
E B(\Delta)=w L^{*}\left[\Delta\left(1-F\left(\hat{\gamma} \mid L^{*}\right)\right)-R_{0}\right]+(1-h) \int_{0}^{\hat{\gamma}} \gamma f\left(\gamma \mid L^{*}\right) d \gamma
$$

where the first term describes the bank's expected profits in solvent states of nature and $R_{0}=1+r_{0}$ with $r_{0}$ being the bank's opportunity cost of granting loans. The second term delineates the expected profits accruing to the bank when bankruptcy occurs. The parameter $\mathrm{h}$ denotes the bankruptcy costs capturing the idea that it may be costly to liquidate a project failing to fulfil the contractual repayment obligation. With $h=0$ we cover the limiting case of a perfectly liquid project with the same value to outsiders as to the firm, while $\mathrm{h}=1$ covers the limiting case where the liquidation of a bankrupt project does not benefit the bank. ${ }^{10}$ From the labour demand (4) we find that the firm's probability of solvency is $\left(1-F\left(\hat{\gamma} \mid L^{*}\right)\right)=e^{1-\eta}$. It is remarkable that this probability is constant and independent of the effective wage rate $\widetilde{w}=\Delta w^{11}$

The combination of (2), whereby the base wage to unionised workers is paid prior to finalisation of production, and (6) means that workers have priority claims relative to banks in case bankruptcy occurs. But, on the other hand, as a residual claimant relative to the "break-even" state of nature, the bank has priority relative to performance-related components in the compensation scheme offered to workers. Using integration by parts we can re-write the expected profit function of the financier as follows

$$
E B(\Delta)=w L^{*}\left[\Delta x(h, \eta)-R_{0}\right]
$$

where $x(h, \eta)$ is defined by $x(h, \eta)=h e^{1-\eta}+(1-h)\left(1-e^{1-\eta}\right) /(\eta-1)$ and where $1-F(\hat{\gamma})=e^{-\lambda\left(L^{*}\right) \hat{\gamma}}=e^{1-\eta}$ denotes the probability of the firm remaining solvent. Thus, the bank's expected profit is an increasing function of the probability of solvency when the bankruptcy costs, $h$, are not too small. ${ }^{12}$

\footnotetext{
${ }^{10}$ For a general discussion of different approaches to bankruptcy procedures and bankruptcy costs, see Hart (2000).

${ }^{11}$ Proof: Substituting the labour demand and the specification for $\lambda(L)$ for the expression of the probability of solvency gives $(1-F(\hat{\gamma}))=e^{-\lambda(L) \hat{\gamma}}=e^{-\frac{\alpha \widetilde{w}^{1-\eta} \eta^{\eta}}{\widetilde{w}^{-\alpha \eta} \eta^{\alpha \eta}}}=e^{1-\eta}$. Q.E.D.

${ }^{12}$ With very small bankruptcy costs the bank would, in fact, have an incentive to "go for the broke". Such a possibility is discussed in Hart (2000). Intuitively it emerges as a consequence of the fact that in the presence of small bankruptcy costs liquidation of the project would yield a high return to the bank.
} 
The repayment rate is assumed to be determined through bargaining between the financier and the firm subject to the constraint that the firm unilaterally determines employment and borrowing in line with the "right-to-manage" approach. ${ }^{13}$ We further assume that zero expected profits represent the threat point of the firm, whereas the opportunity cost of granting funding represents the outside option of the financier. Thus, the determination of $\Delta$ can be modelled as the solution to the following Nash bargaining problem

$$
\operatorname{Max}_{\Delta} \Psi(\Delta)=[E B(\Delta)]^{\mu}\left[(1-\tau) E \pi^{*}(\Delta)\right]^{1-\mu} \text { s.t. } \quad E \pi_{L}^{*}=0
$$

where $\mu$ and $1-\mu$ denote the relative bargaining power of the financier and the firm, respectively. The first-order condition associated with (8) can be expressed as

$$
\mu \frac{E B_{\Delta}}{E B}+(1-\mu) \frac{E \pi_{\Delta}^{*}}{E \pi^{*}}=0
$$

In Appendix A we characterise explicitly the circumstances under which the sufficient second-order condition for the Nash bargaining problem (8) holds ${ }^{14}$. The effect of the repayment rate on the expected profit of the bank is $E B_{\Delta}=\left(w L^{*} / \Delta\right)\left[R_{0} \eta+\Delta x(h, \eta)(1-\eta)\right]$ and by applying the envelope theorem we have $E \pi_{\Delta}^{*}=-w L^{*}(1-F(\hat{\gamma}))=-w L^{*} e^{-\lambda\left(L^{*}\right) \hat{\gamma}}<0$. Combining these formulations the firstorder condition (9) generates the following Nash bargaining solution

$$
\Delta^{N}=\left[\frac{\mu+\eta-1}{\eta-1}\right] \frac{R_{0}}{x(h, \eta)} .
$$

Remembering that $x(h, \eta)=h e^{1-\eta}+(1-h)\left(1-e^{1-\eta}\right) /(\eta-1)$ we can conclude that the negotiated repayment rate depends on five factors: (i) the firm's probability of solvency $\left(e^{1-\eta}\right)$, (ii) the elasticity of labour (and debt) demand ( $\left.\eta\right)$, (iii) the bankruptcy costs (h),

\footnotetext{
${ }^{13}$ Here we follow the 'right -to-manage' approach in the credit market negotiations. While it is common in the analyses of labour markets, one can ask how well it fits credit markets. Concerning credit markets this is a subject for further research.

${ }^{14}$ See, for example, Alexander and Lederman (1996) for an analysis of this issue in a labour market context.
} 
(iv) the relative bargaining power of the financier $(\mu)$ as well as (v) the opportunity cost of granting loans $R_{0}$. The repayment rate depends positively on the relative bargaining power of the financier, the bankruptcy costs and the opportunity cost of granting loans. In the realistic case where the bankruptcy costs are not too small it also depends positively on the probability of bankruptcy $\left(F\left(\hat{\gamma} \mid L^{*}\right)=1-e^{1-\eta}\right)$. We summarise our analysis of the bargaining taking place in the credit market in

Proposition 1 The Nash bargaining repayment rate given by (10) depends positively on the relative bargaining power of the bank, on the opportunity costs of granting loans as well as on the bankruptcy costs. Further, it is positively related to the bankruptcy risk of the project as long as the bankruptcy costs are not too small.

It is worth emphasising that due to the constant effective wage elasticity of labour demand the Nash bargaining solution (10) is independent of the wage rate, $w$, and thereby of the relative bargaining power of the labour market participants.

In the literature there is no unique, standardised way to characterise the intensity of credit market competition. In traditional oligopoly models the consequences of intensified competition are often analysed by increasing the number of competitors. Another approach, frequently applied in industrial organisation, is to measure the intensity of competition by the degree of product differentiation like, for example, in the Hotelling-type models of horizontal product differentiation. A third way of capturing the degree of credit market imperfections is to identify these with the lender's bargaining power relative to that of the borrower, i.e. to apply the Nash bargaining approach, which we have done in the present analysis. ${ }^{15}$ For our purposes this approach has two advantages: it both incorporates the polar market structures of monopoly and perfect competition as special cases and avoids incorporation of market-specific, and often controversial, institutional details of credit markets as a part of the analysis. In this study we have measured credit market imperfections by the bargaining power of the bank.

\footnotetext{
15 This approach can be justified either axiomatically (see Nash (1950)) or strategically (see Binmore, Rubinstein and Wolinsky (1986)). For applications of the Nash bargaining approach to analyze credit market competition in slightly different contexts we refer to Koskela and Stenbacka (2000b), Besci, Li and Wang (2000) and Wasmer and Weil (2002).
} 
A change in the bargaining power of the bank may is not be equivalent, however, to a change in the competitiveness of the credit market. For example, Bester (1995) associates a change in the degree of competitiveness with a change in the outside option of the project holder. Thus, if the credit market becomes more competitive in response to a larger number of banks the outside option available to borrowers improves. But, this does not mean that the bargaining power of the borrowers would have increased. For this reason it is important to repeat that the precise interpretation of reduced credit market imperfections in the context of the present model is equivalent to decreased bargaining power of banks.

\section{2. Compensation Structure}

We now turn to analyse the compensation structure by first studying the base wage negotiations between the union and the firm, both possessing market power and then analysing the issue of optimal profit sharing. In the wage negotiations the firm and the union take the profit share $\tau$ as given and anticipate the optimal employment determination as well as the subsequently negotiated repayment rate in the credit market. ${ }^{16}$

\section{IV.2.1. Wage Bargaining}

We write the linear utilitarian objective function of the trade union as

$$
E \hat{U}(w)=L^{*}\left\lfloor w+\left(\tau / L^{*}\right) E \pi^{*}\right\rfloor+\left(N-L^{*}\right) b
$$

where the first term captures the rent to the employed and the second term that to the unemployed union members. With probability $F\left(\hat{\gamma} \mid L^{*}\right)$ the firm confronts bankruptcy, in which case the worker receives nothing on top of the base wage paid out prior to resolution of uncertainty. With the complementary probability, $1-F\left(\hat{\gamma} \mid L^{*}\right)$, the firm

\footnotetext{
${ }^{16}$ For theoretical completeness it should be remarked that the trade union and firm could a priori make the wage contract contingent on the negotiated interest rate as a way to collectively extract surplus from the bank. For reasons of tractability we do not pursue this issue in our analysis. Furthermore, from other contexts we know that wage contracts reached by a process of collective bargaining are seldom made contingent on macroeconomic performance or other contracts signed by the firm. Of course, in our model the reached wage agreement is contingent on the success in negotiation with the financier, because if there is no credit-financed production, there will be no employment.
} 
remains solvent and the employed union member is remunerated according to the compensation contract, i.e. the sum of the base wage, $w$, negotiated with the firm and the share of the profit realisation, $\tau / L^{*}$, determined by the firm. Note that these probabilities are incorporated in the objective function of the union through the expected profits $E \pi^{*}$. The parameter $b$ denotes the trade union's outside option.

We denote the relative bargaining power of the union by $\beta$, and that of the firm by $(1-\beta)$, and assume that the threat points of the trade union and the firm are described by $E U^{o}=N b$ and $E \pi^{o}=0$, respectively. Applying the Nash bargaining solution the negotiating parties decide on the base wage $w$ in order to solve

$$
\operatorname{Max}_{w} \Omega(w)=[E U(w)]^{\beta}\left[(1-\tau) E \pi^{*}(w)\right]^{1-\beta} \text { s.t. } \Psi_{\Delta}=E \pi_{L}^{*}=0
$$

where $E U=E \hat{U}-E U^{o}=L^{*}\left[(w-b)+\left(\tau / L^{*}\right) E \pi^{*}\right\rfloor$ and $E \pi^{*}=e^{1-\eta} / \lambda\left(L^{*}\right)$. The Nash bargaining solution satisfies the following first-order condition ${ }^{17}$

$$
\Omega_{w}=0 \Leftrightarrow \quad \beta \frac{E U_{w}}{E U}+(1-\beta) \frac{E \pi_{w}^{*}}{E \pi^{*}}=0
$$

where we can calculate that $E U_{w}=\left(L^{*} / w\right)\left[w(1-\eta)+b \eta+\left(\tau / L^{*}\right)(1-\eta) E \pi^{*}\right]>0$ and $E \pi_{w}^{*}=-\frac{e^{1-\eta}(\eta-1)}{w \lambda\left(L^{*}\right)}<0$, respectively. Utilising these we can explicitly solve the firstorder condition (12) to find the following Nash bargaining solution

$$
w^{N}=\frac{\beta+\eta-1}{\eta-1+\tau \Delta^{N} e^{1-\eta}} b=\frac{(\beta+\eta-1)}{(\eta-1)+\tau \frac{(\mu+\eta-1)}{(\eta-1)} \frac{e^{1-\eta} R_{0}}{x(h, \eta)}} b
$$

In Appendix B we characterise the plausible circumstances under which the sufficient second-order condition associated with the Nash bargaining problem (11) are satisfied. In general, according to (13) the negotiated wage rate is a multiple of the outside option. This multiple depends positively on the relative bargaining power of the trade union and

\footnotetext{
17 We assume that the sufficient second-order condition for the Nash bargaining problem holds.
} 
negatively on the bargaining power of the financier in the credit market as long as the firm adopts profit sharing. Moreover, the magnitude of the profit share applied as well as the opportunity cost of granting loans, $r_{0}$, have wage-moderating effects. In the limiting case with $\mathrm{h}=1$ the negotiated base wage takes the form

$$
\left.w^{N}\right|_{h=1}=\frac{(\beta+\eta-1)}{(\eta-1)+\tau \frac{(\mu+\eta-1)}{(\eta-1)} R_{0}} b .
$$

We summarise our characterisation of the negotiated base wage in

Proposition 2 In the presence of profit sharing the Nash bargaining solution with respect to the base wage rate is decreasing as a function of the profit share, the relative bargaining power of the financier and the opportunity cost of granting loans.

Hence the negotiated wage depends on the credit market imperfections. The negotiated wage is negatively related to the banks' bargaining power when wage contracts incorporate a performance-related component in the form of profit sharing.

\section{IV.2.2. Determination of Profit Sharing}

As we discussed earlier in section II, profit sharing is a common phenomenon in industrialised economies. We now proceed to analyse the firm's optimal commitment to the wage structure in the form of a profit share within the framework of our model. As we have seen in the previous sections the profit share will subsequently impact on the negotiated base wage and thereby on employment. The firm decides on the profit share in order to solve the following optimisation problem ${ }^{18}$

$$
\operatorname{Max}_{\tau}(1-\tau) E \pi^{*}=(1-\tau) \frac{e^{-\lambda\left(L^{*}\right) \hat{\gamma}}}{\lambda\left(L^{*}\right)} \quad \text { s.t. } \Omega_{w}=\psi_{\Delta}=E \pi_{L}^{*}=0
$$

where $L^{*}=\left[w^{N} \Delta^{N}\right]^{-\eta} \eta^{\eta}$ and $\hat{\gamma}=w^{N} \Delta^{N} L^{*}$. The first-order optimality condition is

\footnotetext{
18 A number of contributions to the literature on wage bargaining, for example, Jerger and Michaelis (1999), Holmlund (1991), Pohjola (1987) and Anderson and Devereux (1989) have analyzed profit shar-
} 


$$
\underbrace{-E \pi^{*}\left(w^{N}, \Delta^{N}\right)}_{-}+\underbrace{(1-\tau) E \pi_{w}^{*} \frac{\partial w^{N}}{\partial \tau}}_{+}=0
$$

where

$$
E \pi_{w}^{*}=-\frac{e^{1-\eta}(\eta-1)}{w^{N} \lambda\left(L^{*}\right)}<0 \text { and } \frac{\partial w^{N}}{\partial \tau}=-w^{N} \frac{e^{1-\eta} \Delta^{N}}{\eta-1+\tau e^{1-\eta} \Delta^{N}}<0 .
$$

According to the first-order condition (15) the optimal profit share is determined so that the negative dilution effect (the first term) is counterbalanced by the positive wagemoderating effect of the profit share $\tau$ (the second term). ${ }^{19}$ Substituting (16) into (15) and rearranging gives the following explicit solution

$$
\tau^{*}=\frac{(\eta-1)}{\eta}\left[\frac{e^{1-\eta} \Delta^{N}-1}{e^{1-\eta} \Delta^{N}}\right]
$$

where the negotiated repayment rate $\Delta^{N}$ is subsequently determined by (10). One can see that profit sharing is adopted by the firm if $e^{1-\eta} \Delta^{N}>1$. We can define the value of the critical bankruptcy cost $h^{*}$, defined as $x\left(h^{*}\right)=\frac{\mu+\eta-1}{\eta-1} e^{1-\eta}$, for which the optimal profit sharing is zero. Because $\left(\partial \tau^{*} / \partial h\right)=\left(\partial \tau^{*} / \partial \Delta^{N}\right)\left(\partial \Delta^{N} / \partial h\right)>0$ profit sharing is utilised if $h>h^{*}$, which means that higher bankruptcy costs make it more likely that the firm will adopt profit sharing. Such a relationship between profit sharing and bankruptcy costs appeals to intuition, since higher bankruptcy costs increase the negotiated interest rate, which in turn enhances the incentives for profit sharing. In the limiting case with $h=1$ we can write the optimal profit share as

$$
\left.\tau^{*}\right|_{h=1}=\frac{\eta-1}{\eta} \frac{\mu R_{0}+(\eta-1) r_{0}}{(\mu+\eta-1) R_{0}}
$$

ing within a framework where the union-firm negotiations include profit shares in addition to base wages. All of these studies abstract from credit market imperfections.

${ }^{19}$ Efficiency wage considerations are outside the scope of our model. Of course, the presence of incentive problems would strengthen the arguments for the use of profit shares by adding a positive effortenhancing effect. 
According to (18) the optimal profit share increases with the relative bargaining power of the financier, because the induced base wage moderation stimulates the firm's use of profit sharing. Analogously, by a similar wage-moderating effect an increase in the opportunity cost of granting loans will promote the use of profit sharing. Finally, the firm's incentives to use the instrument of profit sharing are not affected by the degree of competition in the labour market, because the repayment rate (10) is independent of the wage rate. The repayment rate is independent of the wage rate because in our model the wage elasticity of labour demand is constant due to the assumption of the Cobb-Douglas production function. With more general production functions this might not hold. We summarise our findings in

Proposition 3 The optimal profit share is increasing as a function of the relative bargaining power of the bank in the credit market, while independent of the bargaining power of the firm in the labour market. Higher bankruptcy costs increase the likelihood and degree of profit sharing. Finally, higher opportunity costs of granting loans promote the use of profit sharing.

Thus, lower bargaining power of the financier induces a shift towards a lower degree of performance-related pay, which will generate a higher base wage. This indirect effect, operating through the induced optimal profit share, works in the same direction as the direct base wage-reducing effect of lower bargaining power of the financier.

In separate calculations we have developed the theoretical benchmark case with simultaneous bargaining with respect to both profit shares and base wages. Our calculations in that respect show that under simultaneous bargaining about the compensation structure the base wage depends negatively on the bargaining power of the financier, while it is independent of the trade union's bargaining power. This means that with simultaneous bargaining the trade union has an incentive to channel all its relative bargaining power to the profit share rather than allocating some fraction of it to impact on the base wage. Moreover, if we abstract from credit market imperfections by assuming that the bargaining power of the financier $\mu=0$, we obtain as a special case the results presented in the literature: $w^{N}=b$ and $\tau^{N}=\beta$. Thus, in the absence of credit market imperfections the base wage is equal to the outside option, while the profit share is com- 
completely determined by the relative bargaining power of the trade union (see e.g. Anderson and Devereux (1989) and Holmlund (1991)). ${ }^{20}$

\section{Equilibrium Unemployment, Credit Market Imperfections and Profit Sharing}

Having studied the interaction between the determination of the compensation structure and the repayment rate we now integrate the elements developed so far in order to explore the consequences of imperfections in the labour and credit markets for total employment. Earlier we observed that the negotiated base wage is an increasing function of the trade union's relative bargaining power, whereas a decreasing function of the bank's relative bargaining power in the credit market as long as profit sharing schemes are adopted. Throughout our analysis the outside option of the trade union members was exogenous. Next we elaborate this issue in a more detailed way.

\section{V.1. Unemployment Benefit as the Outside Option: A Partial Equilibrium Analysis}

Let us first consider how the degree of credit market imperfection, measured by the relative bargaining power of the financier, $\mu$, impacts on employment when labour is immobile across industries. With labour immobility the exogenous unemployment benefit constitutes the relevant outside option for workers at the stage of wage negotiations. Under labour immobility the employment effect of a change in $\mu$ can be expressed as

$$
\frac{d L}{d \mu}=\underbrace{L_{\widetilde{w}} w^{N}\left[\frac{\partial \Delta^{N}}{\partial \mu}\right]}_{-}+\underbrace{L_{\widetilde{w}} \Delta^{N}\left[\frac{\partial w^{N}}{\partial \mu}+\frac{\partial w^{N}}{\partial \tau^{*}} \frac{\partial \tau^{*}}{\partial \mu}\right]}_{+} .
$$

Thus, there are three mechanisms via which an increase in $\mu$ influences employment. Firstly, there is the direct effect, whereby the employment falls as a consequence of an increase in the negotiated repayment rate factor (the first term on the RHS). In addition, there are two offsetting effects operating through the compensation formation. The negotiated wage rate is moderated directly through an induced reduction in the base wage 
and indirectly via an induced increase in the profit share. Both of these wagemoderating effects stimulate employment (the second term on the RHS).

Substituting the relevant expressions into (19) and rearranging gives

$$
\frac{d L}{d \mu}=\frac{w L_{\widetilde{w}}}{\eta-1+\tau e^{1-\eta} \Delta^{N}}\left(\frac{\eta-1}{\eta} \frac{R_{0}}{x(h, \eta)}\right)<0 .
$$

Thus, we can conclude that the direct effect of a change in the relative bargaining power of the bank dominates the indirect effects, taking place via the wage and the profit share determination, independently of the relative size of the bargaining power of trade union in the labour market. Consequently, with an immobile labour force and exogenous outside option lower bargaining power of banks in the credit market unambiguously yields lower unemployment. We can summarise our findings in the absence of labour mobility in

Proposition 4 With immobile labour force and exogenous unemployment benefits reduced credit market imperfections will lower equilibrium unemployment.

\section{V.2. Equilibrium Unemployment: A General Equilibrium Analysis}

Next we investigate how credit and labour market imperfections will impact on equilibrium unemployment when labour is mobile across industries. ${ }^{21}$ According to (13) for each industry the negotiated wage has the form

$$
w_{i}^{N}=\mathrm{A}_{i} b
$$

where the mark-up factor $\mathrm{A}_{i}=\frac{\beta+\eta-1}{\eta-1+\tau \Delta^{N} e^{1-\eta}}$ is, in principle, industry-specific. We assume that all industries are identical in the sense that $A_{i}=A$. In a general equilibrium context with labour mobility across identical industries, which all apply profit sharing,

\footnotetext{
${ }^{20}$ These results together with the details of the analysis are available from the authors upon request.

${ }^{21}$ This useful distinction between the frameworks associated with partial and general equilibrium models is applied in a slightly different context in Layard and Nickell (1990).
} 
the outside option $b$ is now, in line with, for example, Jerger and Michaelis (1999), interpreted to be

$$
b=(1-u)\left[w+\frac{\tau E \pi^{*}}{L}\right]+u B
$$

where $\mathrm{u}$ denotes the unemployment rate, $\mathrm{B}$ the unemployment benefit, $\tau$ is the profit share and $\mathrm{w}$ is the negotiated wage rate in all the identical industries. ${ }^{22}$ Thus, the economy-wide base wage, the rate of profit sharing and the unemployment benefit are those components of the outside option which are relevant for the wage negotiation.

From (22) we can directly conclude that reduced credit market imperfections will impact on the outside option available to the trade union in a general equilibrium context through several mechanisms. In particular, lower bargaining power of banks will increase the base wage, and thereby contribute to an increase in the outside option, while it will also induce lower profit shares, which affects the outside option in the opposite direction. In the subsequent analysis we will be able to compare these opposite effects and thereby to evaluate the overall employment consequences of reduced credit market imperfections.

In line with the literature we further restrict ourselves to the case of a constant benefit-replacement ratio $q \equiv B / w$. Combining (21) and (22) the equilibrium unemployment can then be expressed as

$$
u^{N}=\frac{1-\frac{1}{A}+X \tau \Delta}{1-q+X \tau \Delta},
$$

where $X=\frac{e^{1-\eta} \eta^{2}}{\eta-1}>0$ and where $A>1$ denotes the mark-up factor between the outside option $b$ defined by (22) and the negotiated base wage $w^{N}$.

Differentiating (23) with respect to the bargaining power of the financier $\mu$ remembering that $\mu$ affects the unemployment rate through the mark-up factor $A$, the repayment rate $\Delta$ as well as the profit sharing $\tau$ - yields the following relationship

\footnotetext{
${ }^{22}$ For a standard justification of this interpretation we refer to Layard et.al (1991) p. 100-101 and Nickell and Layard (1999), p. 3048-3050)).
} 


$$
\frac{\partial u^{N}}{\partial \mu}\left\{\begin{array}{l}
> \\
= \\
<
\end{array}\right\} 0 \text { if and only if } \quad q\left\{\begin{array}{l}
< \\
= \\
>
\end{array}\right\} g(\beta, \eta) \equiv 1-\frac{\beta \eta^{2}}{(\beta+\eta-1)(\eta-1)} .
$$

The function $g(\beta, \eta)$, defined in (24), is strictly decreasing as a function of $\beta$ with $g_{\beta}(\beta, \eta)=-\eta^{2} /(\beta+\eta-1)^{2}<0$ and it satisfies the boundary conditions $g(0, \eta)=1$ and $g(1, \eta)=-1 /(\eta-1)<0$.

From (24) we can conclude that the impact of credit market imperfections on equilibrium unemployment is determined by the interplay between labour market institutions (captured by $\beta$ ), labour market policy (captured by the replacement ratio q) and market conditions (captured by $\eta$ ). This interplay is illustrated in Figures 3-4, which are drawn in the $(q, \beta)$ - space. In Figure 3, which refers to the case with the wage elasticity of labour demand $\eta=2$, the downward sloping line describes the locus of those $(q, \beta)$ combinations at which the equilibrium unemployment is invariant to the bargaining power of the bank. On the right-hand side of this line higher credit market imperfections will reduce equilibrium unemployment, whereas the reverse holds on the left-hand side. In Figure 4 we illustrate the effect of changes in the wage elasticity of labour demand $(\eta)$. From Figure 4 we can conclude that more elastic labour demand induces an expansion of the region in which intensified credit market competition reduces equilibrium unemployment. This expansion continues until we approach the borderline $q=1-\beta$, which corresponds to the limit (and, of course, hypothetical) case of infinite labour demand elasticity.

Figures 3 and 4 here

From (24), and as illustrated by Figures 3 and 4, we can generally conclude that reduced credit market imperfections tends to increase equilibrium unemployment as long as the labour market imperfection, measured by the relative bargaining power of trade unions $(\beta)$, is large enough. This is consistent with the argument of the previous subsection focusing on unions operating with an outside option reflecting only base wages. With profit sharing being a part of the outside option of trade unions sufficiently low replacement ratios (q) might cause reduced credit market imperfections to stimulate employment provided that the bargaining power of trade unions is sufficiently small. 
Intuitively, with attention restricted to outside options based on base wages alone, an increase in the repayment rate induces (base) wage moderation and labour force mobility induces the value of the outside option to decrease so as to outweigh the increased direct cost of financing. As profit sharing induces base wage moderation it is natural that introduction of profit shares into the outside option will reduce the magnitude of the employment-enhancing "outside option" effect. For the combination of a sufficiently low replacement ratio and sufficiently small bargaining power of trade unions this reduction in the "outside option" effect will make the direct funding cost effect dominate. These findings, which represent a culmination of our analysis, are stated in the following proposition.

Proposition 5 With mobile labour and with profit sharing being part of the outside option, reduced credit market imperfections will raise equilibrium unemployment when labour market imperfections ( $\beta$ ) are large enough. But if the labour market imperfections are sufficiently small, intensified credit market competition will reduce equilibrium unemployment in the presence of policies with a sufficiently low benefitreplacement ratio (q). Finally, higher labour demand elasticity will, ceteris paribus, extend the region in which intensified credit market competition reduces equilibrium unemployment.

A careful inspection of (10), (13), (19) and (21) shows that we can explore the impact on equilibrium unemployment of a change in the bank's opportunity cost of granting loans in a completely analogous way. Such an analysis reveals that the equilibrium unemployment increases in response to banks facing lower opportunity costs of granting credit. To the extent that we identify expansive monetary policy with lower interest rates in the sense of access to lower costs of funding for the banks we can formulate

Corollary 1 With mobile labour and with profit sharing being part of the outside option, a monetary policy expansion will raise equilibrium unemployment when labour market imperfections (measured by $\beta$ ) are large enough. But if the labour market imperfections are sufficiently small, a monetary policy expansion will reduce equilibrium unemployment in the presence of policies with a sufficiently low benefit-replacement ratio $(q)$. 
Corollary 1 can intuitively be explained in a way completely analogous to that of Proposition 5.

As for the relationship between equilibrium unemployment and credit market imperfections under simultaneous bargaining of base wage and profit share one can show that the equilibrium unemployment depends positively on the bargaining power of financiers. ${ }^{23}$ In fact, the profit share will always be higher with simultaneous bargaining. This ordering reflects that the bargaining power of trade unions is directed to the profit share under simultaneous bargaining, whereas it is, by definition, directed to the base wage under sequential determination of profit share and base wage. In light of (22) the credit market imperfection will affect the outside option via two channels: the base wage and profit sharing. In general, lower bargaining power of banks will increase the base wage and thereby the outside option, while it will induce higher profit sharing, which affects the outside option in the opposite direction. It was shown earlier in this section that the "profit sharing effect" could dominate with sequential determination of profit share and base wage only if the labour market imperfection is "small enough" (see Proposition 5). In contrast, with simultaneous bargaining the profit sharing channel becomes stronger and it can be shown to always dominate the base wage effect.

\section{V.3 Bankruptcy Risks and Equilibrium Unemployment}

Our model incorporates bankruptcy risks. Clearly, the presence of bankruptcy risks is a way of motivating debt contracts, because debt contracts would no longer be optimal if we eliminated uncertainty and thereby bankruptcy risks. But, we have not yet systematically explored the relationship between bankruptcy risks and equilibrium unemployment within the framework of our model. In the present subsection we will precisely address this issue by asking the following question. Which are the effects of increased bankruptcy risks on wage formation and equilibrium unemployment?

We initially focus on the case with $h=1$, which covers the limiting case where the funded project would be completely illiquid from the point of view of the bank. By substituting $h=1$ into the negotiated repayment rate (10), the negotiated base wage (13), the equilibrium profit share (18) and finally into the equilibrium unemployment rate (23) we can conclude that the equilibrium unemployment rate is independent of the bankruptcy risk. In fact, for $h=1$ the compensation structure will be independent of the

${ }^{23}$ A formal proof of this result is available from the authors upon request. 
bankruptcy risks, since both the negotiated based wage and the equilibrium profit share will be invariant to the bankruptcy risk. However, as we will see below, the invariance of the equilibrium unemployment rate to the bankruptcy risks is specific to this particular case with $h=1$.

In Appendix $\mathrm{C}$ we have established that the general effect of the bankruptcy risk on the equilibrium unemployment is determined by the labour market policy. More precisely, Appendix $\mathrm{C}$ shows that higher bankruptcy risks will increase the equilibrium unemployment rate if and only if the labour market policy is characterised by a sufficiently high benefit-replacement ratio. This effect can be traced to how the bankruptcy risk will change the compensation structure. In this respect we demonstrate in Appendix $\mathrm{C}$ the new result that bankruptcy risks will increase the mark-up incorporated in the negotiated base wage, while at the same time reduce the profit share in equilibrium. Hence the compensation structure depends on the bankruptcy risk if the funded project is not completely illiquid from the point of view of the bank. In light of the outside option available for the union, $b=(1-u)\left[w+\frac{\tau E \pi^{*}}{L}\right]+u q w$, we can see that the relative weight of the base wage channel increases as a function of the replacement ratio. Thus, for a sufficiently high benefit-replacement ratio the base wage effect will dominate, meaning that increased bankruptcy risks will lead to higher compensation and thereby lower employment.

As (C6) in Appendix C shows, the critical benefit-replacement ratio, above which bankruptcy risks increase equilibrium unemployment, depends negatively on the labour market imperfections measured by the bargaining power of the trade union $(\beta)$. In other words, increased labour market imperfections will lower the critical benefitreplacement ratio above which higher bankruptcy risks will increase equilibrium unemployment.

We summarise our findings in this section by formulating the following proposition.

Proposition 6 Higher bankruptcy risks will increase equilibrium unemployment if the benefit-replacement ratio exceeds a critical threshold, which is a decreasing function of the bargaining power of the union. However, in the special case where the funded project is completely illiquid from the point of view of the bank the equilibrium unemployment will be independent of the bankruptcy risks. 
Proposition 6 again emphasises the complementarity between the labour market institutions and the labour market policies. Higher bankruptcy risks will harm employment in the presence of sufficiently generous systems of unemployment compensation. It is more likely for the labour market policy to exceed this critical threshold with increased labour market imperfections. In this respect the combination of generous systems of unemployment compensation and substantial labour market imperfections tend to make the employment more vulnerable when the economy is faced with increased bankruptcy risks.

\section{Concluding Comments and Policy Implications}

This study has focused on the role of labour and credit market imperfections as well as the role of the interaction between these for the determination of equilibrium unemployment within the framework of the "right-to-manage" approach when the profit sharing is a part of the compensation structure. In the credit market the repayment rate is negotiated between financiers and firms, both possessing bargaining power, while the firms and the organised labour bargain over the base wage. These two types of negotiations take place sequentially. The labour and credit market negotiations have been assumed to take place conditional on the firm having committed itself to the form of wage contract determining to what extent it makes use of performance-related profit sharing in addition to the negotiated base wage.

The presence of a performance-related wage component in the form of profit sharing has been shown to be a necessary condition for the relationship between the credit market imperfections and equilibrium unemployment when the wage elasticity of labour demand is constant. ${ }^{24}$ Our analysis has highlighted the critical role of labour mobility for the evaluation of the employment implications of reduced credit market imperfections. Without labour mobility, increased bargaining power of banks in the credit market will have adverse employment effects, because it increases negotiated base wages in a straightforward way. In fact, our study has confirmed the following intuitively appealing conjecture. Reduced credit market imperfections will promote employment if the labour force is (1) immobile across industries or (2) mobile across in-

\footnotetext{
${ }^{24}$ If the wage elasticity of labour demand is not constant, there might be additional mechanisms generating a relationship between credit markets and equilibrium unemployment. Credit market imperfections
} 
dustries where all firms adopt profit sharing as long as labour markets exhibit sufficiently small bargaining power of trade unions and face policies with sufficiently low benefit-replacement ratios.

However, with a labour force mobile across industries the relationship between credit market imperfections and equilibrium unemployment is reversed if the labour market imperfections - measured by the relative bargaining power of the trade unions are sufficiently strong. Namely when union members have access to an outside option consisting of a probability-weighted average of wage-related unemployment compensation (with a probability equal to the unemployment rate) and performance-related compensation in another industry (with the complementary probability) the wagemoderating effect of a higher repayment rate will promote employment to such an extent as to offset the harmful direct effect of higher lending rates. In this way reduced credit market imperfections can actually harm employment if the labour market imperfections are sufficiently strong. We can explain such a relationship between credit market imperfections and equilibrium unemployment in the following way. With sufficiently strong bargaining power of trade unions in the labour markets credit market imperfections will actually serve as a disciplining device whereby the potential of the trade union to exploit this bargaining power is reduced in an efficiency-enhancing way. The introduction of an additional distortion in the form of credit market imperfections improves the performance of the labour market, which suffers from a primary distortion with its roots in the bargaining power of the trade union. ${ }^{25}$

Our model emphasises the "first-order" importance of institutional policies directed at reducing the labour market imperfections under those circumstances where profit sharing in other industries is part of the outside option for workers. Namely, in light of our model society will not be able to benefit in terms of employment from intensified credit market competition as long as the primary labour market imperfections are dominant. From (27), and as illustrated in Figures 3 and 4, labour market institutions, where the relative bargaining power of trade unions exceeds 0.33 , will under all circumstances prevent higher efficiency of credit markets to spill over to improved employment performance. Such magnitudes of relative bargaining power of trade unions - measured

might affect the wage elasticity of labour demand and thereby wage formation. This lies beyond the scope of our paper. 
either in terms of trade union density rates and/or in terms of collective bargaining coverage - do seem to fit observations from European countries (see Nickell and Layard (1999), p. 3041 and DICE database collected by CESifo, http://www.CESifo.de). Thus, links to other markets, such as the credit market, add to the social return from reforms reducing the imperfections in labour markets. This argument seems more relevant the higher is the degree of labour force mobility.

In a world with labour force mobility and where firms widely apply performance-based wage schemes in the form of profit sharing, labour market policies intended to reduce the benefit-replacement ratio can play a role in shifting the economy from a state where the development towards reduced credit market imperfections harms employment into one where this development promotes employment. Nevertheless, policies to reduce benefit-replacement ratios $(q)$, which are high in European countries (see Nickell and Layard (1999), p. 3045 and DICE database collected by CESifo, http://www.CESifo.de), seem to play a more limited role relative to the bargaining power of trade unions $(\beta)$. Finally, higher labour demand elasticity, which may result from increasing economic integration, will potentially increase the role of policies to reduce benefit-replacement ratios $(q)$ as a higher elasticity extends the region in which intensified credit market competition is beneficial for the development of employment.

We have also demonstrated that higher bankruptcy risks will imply higher equilibrium unemployment if and only if the benefit-replacement ratio exceeds a critical threshold. $^{26}$ The critical benefit-replacement ratio is a decreasing function of the bargaining power of the union. Thus, also in this respect our model suggests an important complementarity between institutions and policy in the labour market. Higher bankruptcy risks will harm employment in the presence of a sufficiently generous benefitreplacement ratio. It is more likely for the labour market policy to exceed this critical threshold with increased labour market imperfections. In this respect the combination of high benefit-replacement ratio and substantial labour market imperfections tends to make the employment performance more vulnerable when the economy is faced with increased bankruptcy risks.

\footnotetext{
${ }^{25}$ This argument is analogous to the classical second best analysis by Lipsey and Lancaster (1956-57), according to which it is not necessarily desirable from a welfare point of view to decrease distortions in one particular market if several markets face distortions.

${ }^{26}$ However, in the special case where the funded project is completely illiquid from the point of view of the bank the equilibrium unemployment will be independent of the bankruptcy risks.
} 
References:

Acemoglu, D. (2001) "Credit Market Imperfections and Persistent Unemployment", European Economic Review, 45, 665-679.

Alexander, C.O. - Lederman, W. (1996): "Are Nash Bargaining Wage Agreements Unique? An Investigation into Bargaining Sets for Firm-Union Negotiations", Oxford Economic Papers, 48, 242-253.

Anderson, S. - Devereux, M. (1989) "Profit Sharing and Optimal Labour Contracts", Canadian Journal of Economics, 89, 425-433.

Becsi, Z - Li, V. - Wang, P. (2000) "Financial Matchmakers with Heterogenous Borrowers", Federal Reserve Bank of Atlanta WP 2000-14, September.

Bester, H, (1995) "A Bargaining Model of Financial Intermediation”, European Economic Review, 39, 211-228.

Binmore, K.G. - Rubinstein, A. - Wolinsky, A. (1986) "The Nash Bargaining Solution in Economic Modelling", Rand Journal of Economics, 17, 176-188.

Blanchard, O. - Giavazzi, F. (2003) "Macroeconomic Effects of Regulation and Deregulation in Goods and Labor Markets", Quarterly Journal of Economics, $118,879-907$.

Bronars, S.G. - Deere, D.R. (1991) "The Threat of Unionization, the Use of Debt and the Preservation of Shareholder Wealth", Quarterly Journal of Economics, 56, 231-244.

Caballero, R.J. - Hammour, M.L. (1998): "Improper Churn: Social Costs and Macroeconomic Consequences", NBER Working Paper No.6717.

Cahuc, P. - Dormont, B. (1997) "Profit Sharing: Does it Increase Productivity and Employment? A Theoretical Model and Empirical Evidence on French Micro Data", Labour Economics, 4, 293-319.

Conyon, M. - Freeman, R. (2001) "Shared Modes of Compensation and Firm Performance: UK Evidence", NBER Working Paper \#8448.

Dalmazzo, A. (1996) "Debt and Wage Negotiations: A Bankruptcy-Based Approach", Scandinavian Journal of Economics, 98(3), 351-364.

Dasgupta, S. - Sengupta, K. (1993) "Sunk Investment, Bargaining, and Choice of Capital Structure", International Economic Review, 34, 203-220.

Dell'Ariccia, G. - Friedman, E. - Marquez, R. (1999) "Adverse Selection as a Barrier to Entry in the Banking Industry", Rand Journal of Economics, 30, 515534.

Funke, M. - Maurer, W. - Strulik, H. (1999) "Capital Structure and Labour Demand: Investigations Using German Micro Data”, Oxford Bulletin of Economics and Statistics, 61, 199-215.

Hanka, G. (1998) "Debt and the Terms of Employment", Journal of Financial Economics, 48, 245-282.

Hart, O. (2000) "Different Approaches to Bankruptcy", NBER Working Paper No. 7921.

Holmlund, B. (1991) "Profit Sharing, Wage Bargaining and Unemployment", Economic Inquiry, 28, 257-268.

Jerger, J. - Michaelis, J. (1999) "Profit Sharing, Capital Formation and the NAIRU", Scandinavian Journal of Economics, 101, 257-275.

Koskela, E. - Stenbacka, R. (2000a) "Is There a Tradeoff between Bank Competition and Financial Fragility?", Journal of Banking \& Finance, 24, 1853-1873.

Koskela, E. - Stenbacka, R. (2000b) "The Agency Cost of Debt and Lending Market Competition: A Re-Examination”, Bank of Finland Discussion Papers, 
$12 / 2000$

Koskela, E. - Stenbacka, R. (2001) "Equilibrium Unemployment with Credit and Labour Market Imperfections", CESifo Working Paper No. 419.

Krueger, A. - Pischke, J.-S. (1997) "Observations and Conjectures on the U.S. Employment Miracle", National Bureau of Economic Research (NBER) Working Paper 6146.

Layard, R. - Nickell, S. (1990) "Is Unemployment Lower if Unions Bargaining over Employment", Quarterly Journal of Economics, 773-787.

Layard, R. - Nickell, S. - Jackman, R. (1991) Unemployment: Macroeconomic Performance and the Labour Market, Oxford University Press.

Lipsey, R.G. - Lancaster, K. (1956-57) "The General Theory of Second Best”, Review of Economic Studies, 24, 11-32.

Nash, J. (1950) "The Bargaining Problem”, Econometrica, 18, 155-162.

Nickell, S. - Layard, R. (1999) "Labour Market Institutions and Economic Performance", in Ashenfelter, O. - Card, D. (eds): Handbook of Labor Economics, Vol 3, Elsevier Science, 3029-3084.

Nickell, S. - Nicolitsas, D. (1999) "How Does Financial Pressure Affect Firms?", European Economic Review, 43, 1435-1456.

OECD Employment Outlook (1995), Chapter 4, Profit Sharing in OECD Countries.

Pendleton, A. - Poutsma E. - van Ommeren J. - Brewster C. (2001) Employee Share Ownership and Profit-Sharing in the European Union. Office for Official Publications of the European Commission, Luxembourg.

Perotti, E.C. - Spier, K.E. (1993) "Capital Structure as a Bargaining Tool: The Role of Leverage in Contract Negotiation”, American Economic Review, 83, 1131-1141.

Pohjola, M. (1987) "Profit Sharing, Collective Bargaining and Employment", Journal of Institutional and Theoretical Economics, 334-342.

Sharpe, S.A. (1990) "Asymmetric Information, Bank Lending, and Implicit Contracts: A Stylized Model of Customer Relationships", Journal of Finance, 45, 1069-1087.

Sharpe, S.A. (1994) "Financial Market Imperfections, Firm Leverage, and the Cyclicality of Employment", American Economic Review, 84, 1060-1074.

Wadhwani, S. - Wall, M. (1990) "The Effects of Profit Sharing on Employment, Wages, Stock Returns and Productivity: Evidence from UK Micro-Data", Economic Journal, 100, 1-17.

Wasmer, E. - Weil, P. (2002): "The Macroeconomics of Labour and Credit Market Imperfections", CEPR Discussion Paper No. 3334.

Weitzman, M. (1987) "Steady State Unemployment under Profit Sharing”, Economic Journal, 97, 86-105.

\section{APPENDIX A: Second-order condition for the repayment rate bargaining in the credit market}

The second-order condition for the Nash bargaining problem (8) can be written as

$$
\Psi_{\Delta \Delta}=\frac{\mu}{(E B)^{2}}\left[(E B)\left(E B_{\Delta \Delta}\right)-\left(E B_{\Delta}\right)^{2}\right]+\frac{1-\mu}{\left(E \pi^{*}\right)^{2}}\left[E \pi^{*} E \pi_{\Delta \Delta}^{*}-\left(E \pi_{\Delta}^{*}\right)^{2}\right]<0
$$


Remembering that $E \pi^{*}=\frac{e^{1-\eta} \eta L^{\frac{\eta-1}{\eta}}}{\eta-1}$ we get

$$
E \pi_{\Delta}^{*}=-\frac{(\eta-1)}{\Delta} E \pi^{*}<0
$$

and

$$
E \pi_{\Delta \Delta}^{*}=-\frac{(\eta-1)}{\Delta} E \pi_{\Delta}^{*}+\frac{(\eta-1)}{\Delta^{2}} E \pi^{*}=\frac{(\eta-1) \eta}{\Delta^{2}} E \pi^{*}>0
$$

This gives

$$
\frac{1-\mu}{\left(E \pi^{*}\right)^{2}}\left[\left(E \pi^{*}\right)\left(E \pi_{\Delta \Delta}^{*}\right)-\left(E \pi_{\Delta}^{*}\right)^{2}\right]=\frac{(1-\mu)(\eta-1)}{\Delta^{2}} \geq 0
$$

As for the first RHS part in (A1) we have, remembering that $E B=w L\left[\Delta x-R_{o}\right]$ where $x=h e^{1-\eta}+(1-h)\left(1-e^{1-\eta}\right) /(\eta-1)$, the following findings

(A4a) $\quad E B_{\Delta}=-\frac{w L\left(x \Delta-R_{o}\right) \eta}{\Delta}+w L x=-\frac{E B \eta}{\Delta}+w L x>0$

and

(A4b) $\quad E B_{\Delta \Delta}=-\frac{E B_{\Delta} \eta}{\Delta}+\frac{E B \eta}{\Delta^{2}}+w L_{\Delta} x=\frac{E B \eta(\eta+1)}{\Delta^{2}}-\frac{2 w L x \eta}{\Delta}$.

This gives

$$
\frac{\mu}{(E B)^{2}}\left[(E B)\left(E B_{\Delta \Delta}\right)-\left(E B_{\Delta}\right)^{2}\right]=-\mu\left[\left(\frac{w L x}{E B}\right)^{2}-\left(\frac{\eta}{\Delta}\right)^{2}\right]
$$

According to the first-order condition of the Nash bargaining (9) we have $(w L x / E B)=((\eta-1)(1-\mu)+\eta) / \Delta . \quad$ Using this gives $\left(\frac{w L x}{E B}\right)^{2}-\left(\frac{\eta}{\Delta}\right)^{2}=\left(\frac{(1-\mu)(\eta-1)[(1-\mu)(\eta-1)+2 \eta]}{\Delta^{2}}\right)$. Substituting this into (A5) and adding up (A3) and (A5) yields

$$
\Psi_{\Delta \Delta}=\frac{(1-\mu)(\eta-1)[1-\mu((1-\mu)(\eta-1)+2 \eta)]}{\Delta^{2}}
$$

Hence $\Psi_{\Delta \Delta}<0$ requires that $(1-\mu)(\eta-1)+2 \eta>1 / \mu$, which is equivalent to the condition

$$
\mu<\frac{3 \eta-1}{\eta-1}
$$

which always holds for $\mu>0$.

QED

\section{APPENDIX B: Second-order condition for the base wage bargaining}

The second-order condition for the Nash bargaining problem (11) can be written as 
(B1) $\Omega_{\Delta \Delta}=\frac{\beta}{(E U)^{2}}\left[(E U)\left(E U_{w w}\right)-\left(E U_{w}\right)^{2}\right]+\frac{1-\beta}{\left(E \pi^{*}\right)^{2}}\left[E \pi^{*} E \pi_{w w}^{*}-\left(E \pi_{w}^{*}\right)^{2}\right]<0$

Remembering that $\left.E U=(L / w) \mid(w-b)+(\tau / L) E \pi^{*}\right\rfloor$ we get

(B2a)

$$
E U_{w}=-\frac{(\eta-1)}{w} E U<0
$$

and

$$
E U_{w w}=-\frac{b L(1+\eta)}{w^{2}}-\frac{(\eta-1)}{w^{2}}(E U \eta+b L)
$$

This gives after some rearrangements

(B3) $\frac{\beta}{(E U)^{2}}\left[(E U)\left(E U_{w w}\right)-\left(E U_{w}\right)^{2}\right]=\frac{\beta}{w^{2}}\left[-(\eta-1)(2 \eta-1)-\frac{2 b L}{E U}-\left(\frac{b L}{E U}\right)\right]<0$

Finally, remembering that $E \pi^{*}=\frac{e^{1-\eta} \eta L^{\frac{\eta-1}{\eta}}}{\eta-1}$ we get

$$
E \pi_{w}^{*}=-\frac{(\eta-1)}{w} E \pi^{*}<0
$$

and

$$
E \pi_{w w}^{*}=\frac{(\eta-1)}{w^{2}} E \pi^{*} \eta>0
$$

This gives

$$
\frac{1-\beta}{\left(E \pi^{*}\right)^{2}}\left[\left(E \pi^{*}\right)\left(E \pi_{w w}^{*}\right)-\left(E \pi_{w}^{*}\right)^{2}\right]=\frac{(1-\mu)(\eta-1)}{w^{2}} \geq 0
$$

Adding up (B3) and (B5) yields after some rearrangements

$$
\Omega_{w w}=-\frac{(\eta-1)}{w^{2}}(2 \eta \beta-1)+\frac{\beta}{w^{2}}\left(-\frac{b L}{E U}\left(2+\frac{b L}{E U}\right)\right)
$$

From the first-order condition (12) we get $(b L / E U)=(\eta-1) / \beta$ so that

(B7) $\Omega_{w w}=-\frac{(\eta-1)}{w^{2}}(2 \eta \beta-1)+\frac{\beta}{w^{2}}\left(-\frac{(\eta-1)(2 \beta+\eta-1)}{\beta}\right)$.

Hence a sufficient condition for the second-order condition $\Omega_{w w}<0$ to hold is

$$
\beta>\frac{2-\eta}{2(\eta-1)} \text {.QED }
$$




\section{APPENDIX C: Proof of Proposition 6}

For $0 \leq h \leq 1$ we can write the equilibrium unemployment rate (23) according to

$$
\frac{\beta+\left(e^{1-\eta} \Delta-1\right) g}{(\beta+\eta-1)\left[1-q+\eta\left(e^{1-\eta} \Delta^{N}-1\right)\right]},
$$

where $g$ is defined by

$$
g=\eta(\beta+\eta-1)-\frac{\eta-1}{\eta}>0 .
$$

Further, we define $z=e^{1-\eta} \Delta^{N}-1$ and find that

$$
z=\frac{R_{0}(\mu+\eta-1)-h(\eta-1)-(1-h)\left(e^{-(1-\eta)}-1\right)}{h(\eta-1)+(1-h)\left(e^{-(1-\eta)}-1\right)} .
$$

In order to characterise how the probability of solvency impacts on the equilibrium unemployment rate we now proceed in two steps. First we determine $\frac{\partial u^{N}}{\partial z}$ and subsequently $\frac{\partial z}{\partial e^{1-\eta}}$.

First we establish that

$$
\frac{\partial u^{N}}{\partial z}=\frac{(1-q)(\eta-1)\left(\eta-\eta^{-1}\right)-q \beta \eta}{(\beta+\eta-1)(1-q+\eta z)^{2}} .
$$

From (C4) we can infer that

$$
\frac{\partial u^{N}}{\partial z}>0 \Leftrightarrow q<\hat{q}
$$

where the threshold benefit-replacement ratio is defined by

$$
\hat{q}=\frac{(\eta-1)\left(\eta-\eta^{-1}\right)}{\beta \eta+(\eta-1)\left(\eta-\eta^{-1}\right)} .
$$

Further, we can calculate that

$$
\frac{\partial z}{\partial e^{1-\eta}}=\frac{R_{0}(\mu+\eta-1)(1-h) e^{-2(1-\eta)}}{\left(h(\eta-1)+(1-h)\left(e^{-(1-\eta)}-1\right)\right)^{2}}>0 .
$$

By combination of (C5) and (C7) we can conclude 
(C8)

$$
\frac{\partial u^{N}}{\partial e^{1-\eta}}>0 \quad \Leftrightarrow \quad q<\hat{q} .
$$

From (C8) we can infer the effect of the bankruptcy risk on the equilibrium unemployment by remembering that the bankruptcy risk is $1-e^{1-\eta}$.

We also explore the impact of the bankruptcy risk on the wage formation and profit sharing. In this respect we find that

$$
\frac{\partial A}{\partial e^{1-\eta}}<0 \text { and } \frac{\partial \tau}{\partial e^{1-\eta}}>0 .
$$

Taken together the effects exhibited in (C9) demonstrate that the bankruptcy risks will affect the compensation structure. The first comparative statics result reported in (C9) means that an increase in the probability of bankruptcy leads to an increase in the markup associated with the negotiated base wage. The second part of (C9) expresses that higher bankruptcy risks will reduce the equilibrium profit share. QED 


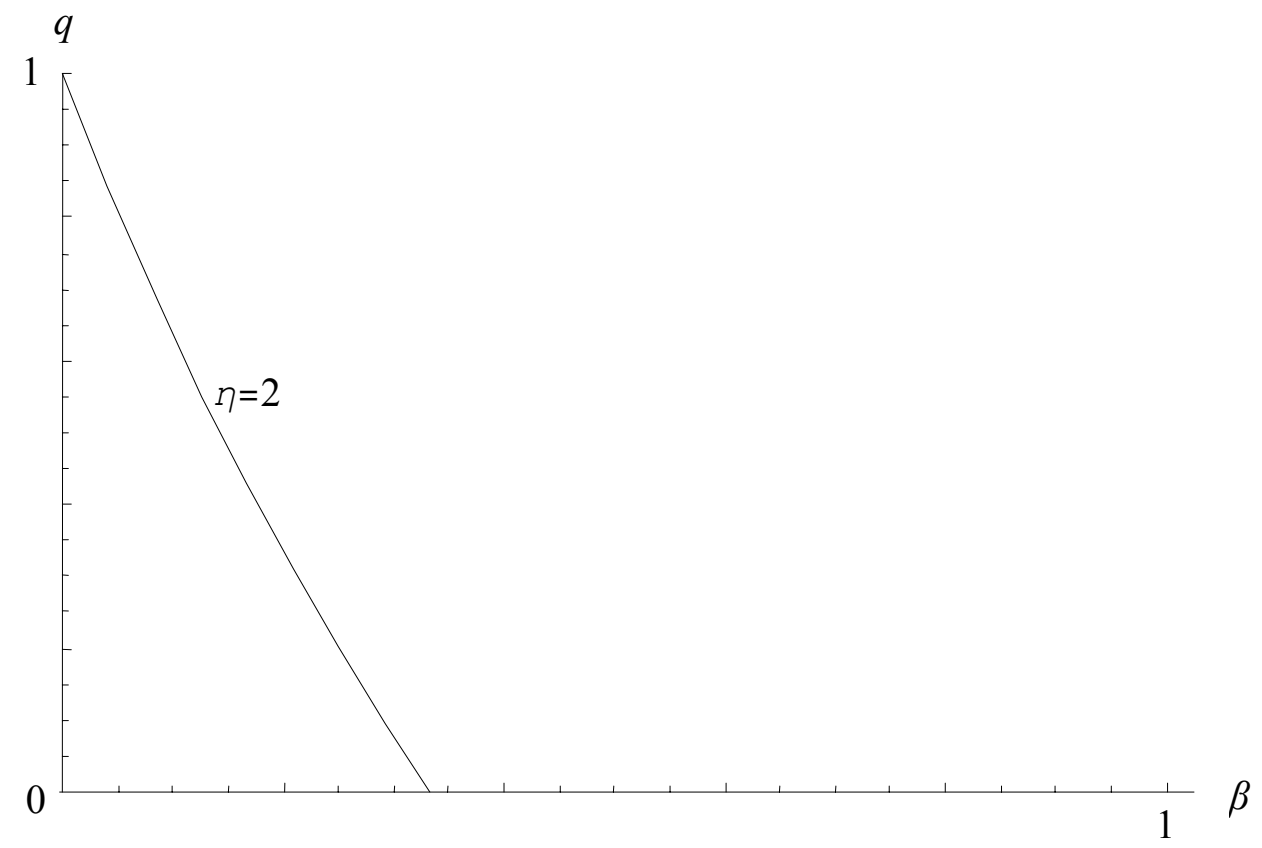

Figure 3. Equilibrium unemployment and credit market imperfections: the role of labour market variables.

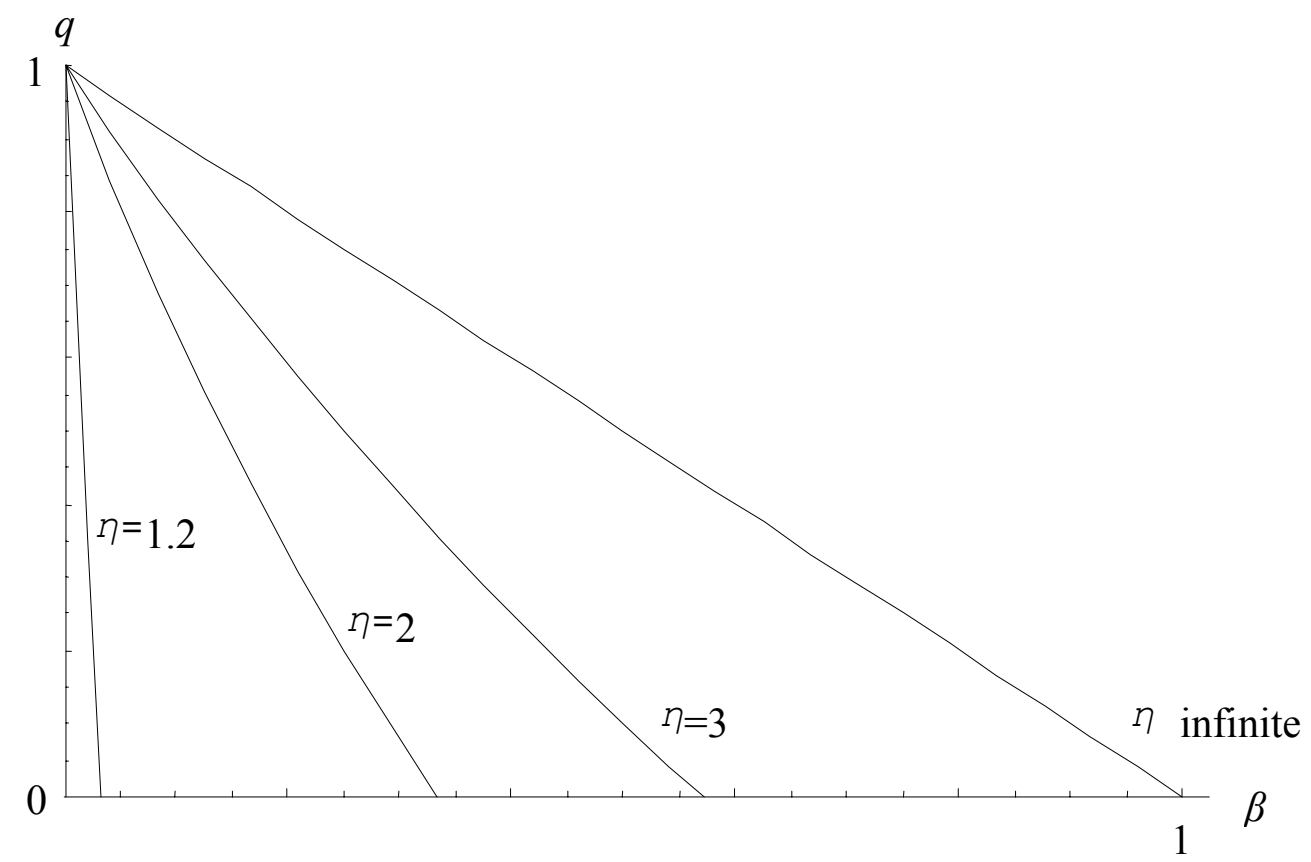

Figure 4. Equilibrium unemployment and credit market imperfections: the role of wage elasticity of labour demand 